\title{
A Smart Right to the City-Grounding Corporate Storytelling and Questioning Smart Urbanism
}

\author{
Anke Strüver ${ }^{1,2, *}$, Rivka Saltiel ${ }^{1}$, Nicolas Schlitz ${ }^{1}{ }^{(\mathbb{C}}$, Bernhard Hohmann $\left.^{2} \mathbb{(}\right)$, Thomas Höflehner ${ }^{2}$ and \\ Barbara Grabher ${ }^{1}$ \\ 1 Department of Geography and Regional Science, University of Graz, 8010 Graz, Austria; \\ rivka.saltiel@uni-graz.at (R.S.); nicolas.schlitz@uni-graz.at (N.S.); barbara.grabher@uni-graz.at (B.G.) \\ 2 RCE Graz-Styria-Centre for Sustainable Social Transformation, University of Graz, 8010 Graz, Austria; \\ bernhard.hohmann@uni-graz.at (B.H.); thomas.hoeflehner@uni-graz.at (T.H.) \\ * Correspondence: anke.struever@uni-graz.at
}

check for updates

Citation: Strüver, A.; Saltiel, R.; Schlitz, N.; Hohmann, B.; Höflehner, T.; Grabher, B. A Smart Right to the City-Grounding Corporate Storytelling and Questioning Smart Urbanism. Sustainability 2021, 13, 9590. https://doi.org/10.3390/ su13179590

Academic Editors: Andreas Koch and Sebastian Kot

Received: 13 July 2021

Accepted: 23 August 2021

Published: 26 August 2021

Publisher's Note: MDPI stays neutral with regard to jurisdictional claims in published maps and institutional affiliations.

Copyright: (c) 2021 by the authors. Licensee MDPI, Basel, Switzerland. This article is an open access article distributed under the terms and conditions of the Creative Commons Attribution (CC BY) license (https:/ / creativecommons.org/licenses/by/ $4.0 /)$.

\begin{abstract}
Against the backdrop of multiple ongoing crises in European cities related to socio-spatial injustice, inequality and exclusion, we argue for a smart right to the city. There is an urgent need for a thorough account of the entrepreneurial mode of technocapitalist smart urbanism. While much of both affirmative and critical research on Smart City developments equate or even reduce smartness to digital infrastructures, we put actual smartness-in the sense of social justice and sustainabilityat centre stage. This paper builds on a fundamental structural critique of (1) the entrepreneurial city (Harvey) and (2) the capitalist city (Lefebvre). Drawing upon Lefebvre's right to the city as a normative framework, we use Smart City developments in the city of Graz as an illustration of our argument. Considering strategies of waste and mobility management, we reflect on how they operate as spatial and technical fixes-fixing the limits of capitalism's growth. By serving specific corporate interests, these technocapitalist strategies yet fail to address the underlying structural causes of pressing urban problems and increasing inequalities. With Lefebvre's ongoing relevant argument for the importance of use value of urban infrastructures as well as his claim that appropriation and participation are essential, we discuss common rights to the city: His framework allows us to envision sustainable and just-actually smart—alternatives: alternatives to technocapitalist entrepreneurial urbanisation. In this respect, a smart right to the city is oriented towards the everyday needs of all inhabitants.
\end{abstract}

Keywords: smart urbanism; entrepreneurial urbanisation; technological fix; waste management; mobility infrastructures; social justice

\section{Introduction}

The present urban crises of smartness encompass the financial crisis, the urban housing, mobility and waste crises, the climate and COVID-19 crises, and also the crisis of the Smart City. All of these crises relate to conditions of socio-spatial injustice, urban inequality and exclusion and therefore need to be regarded in the light of a right to the city [1-3]. In order to discuss the right to the Smart City, we pick up the contemporary global trend to smart(er) cities and advance the debate on smartness as a typical expression of entrepreneurial urbanisation in general [4-7] and "smart cities as corporate storytelling" [8] (p. 307) in particular. Both strands follow Harvey and his critique of neoliberalism [1], uneven spatial development and urban entrepreneurialism-including the privatisation of local urban infrastructures [9]. Despite the wide array of critical publications on smart cities and smart urbanism [10-12], we still miss a critical and emancipatory debate on the right to a Smart City-and a smart right to the city that extends single case studies and evolves from socially smart, just and sustainable ideas and strategies. Going beyond the common equation - or even reduction — of smartness to digital infrastructures and a digital right to the city [13], we put actually smart strategies at the centre stage and argue that 
there is an urgent need for a thorough critique of technocapitalism and an alternative to smart urbanism.

With this paper, we aim to advance the debate on the right to the Smart City and a smart right to the city by (1) relying on social theories well established in critical urban studies and (2) stretching the idea of smartness beyond its common reduction to digitalisation. Following Lefebvre's thoughts on the right to the city in the late 1960s, we stress their continuing - or even increasing - relevance in times of both intensifying urban growth and growing social injustice in the city. Emphasising the importance of use value of urban infrastructures for people as well as appropriation and participation as fundamental and common rights to the city, we will argue for actually smart strategies for any city, employing smart(ness) as emancipatory socio-spatial urban strategies within entrepreneurial urban contexts of Smart City narratives.

Below, we will thus use Smart City developments in the city of Graz to discuss Lefebvre's right to the city as a normative framework for actually smart and just alternatives to smart urbanism driven by technocapitalist urbanisation. However, as there is now an enormous number of Smart City case studies coming to rather critical conclusions regarding their efficiency in terms of economic, ecological and social sustainability, community building and social justice (see, e.g., [14-21]), we will not add another case study. Instead, this paper aims to advance these critical conclusions by framing them with a social theoretical lens well established in critical urban studies: the idea and concept of "a right to the city". This concept allows us to question smart urbanism in a thorough way on the one hand and to focus on socio-spatial contexts of justice and on participation in the sense of integration on the other.

Against the background of this objective, the paper is organised as follows: first, we establish the analytical framework by introducing smart urbanism, entrepreneurial urbanisation and some of Lefebvre's thoughts on the right to the city. After a brief methodological explanation, we elaborate in an illustrative manner on the Smart City Graz (Graz, Austria) along two smart infrastructures-waste and mobility management in the fourth section. The fifth section discusses these examples especially with respect to socio-spatial (in)justice and urban change, and provides the foundation for our concluding thoughts on a socially just city.

\section{Smart Urbanism and Entrepreneurial Urbanisation}

Since the end of the 1990s, urban scholars have addressed the role of information and communication technology (ICT) in the production of urban spaces [22,23], and have critically examined technosocial and technocapitalist transformations, including the shift in power relations in favour of capitalist surplus accumulation. As economic interests play an increasingly important role in the expansion of digital infrastructures in cities, analyses in recent years have also focused on the modernisation promises of dominant Smart City narratives, the expansion of entrepreneurial urbanisation through public-private partnerships, the monitoring, surveillance and control of citizens by ICT companies [11] and, more recently, the emergence of platform urbanism [24-27]. However, since urbanisation processes always involve "not only a transformation of urban infrastructures but also the construction of a new way of life and urban persona" [1] (p. 26), digitalisation must be expected to result in profound changes of cities, its citizens and urban everyday life [28]. Before we turn to this, we will briefly introduce the dominant Smart City narratives (Section 2.1), summarise entrepreneurial urbanisation (Section 2.2) and reflect on the right to the city against this background (Section 2.3).

\subsection{Smart Urbanism}

Given that planetary urbanisation results not just from the increasing number of people worldwide who live in cities but also from the global impact of urbanisation processes [29], we have adopted this as "planetary urban digitalisation" [12] (p. 189): Digital technologies and digitally connected infrastructures in cities, such as mobility 
services, public administration, security surveillance, smart homes and energy grids, amongst others, increasingly shape the production and perception of urban spaces. Recent dynamics of digitalisation in cities are based on new coalitions of ICT corporations and city governments, which foster an understanding of smart urbanism and cities as spaces for technocapitalist control [30]. Labelling this collaboration through the term 'Smart City' does not necessarily serve as a status marker for a city; rather, the label promises an expansion of its level of digitalisation. There is a wide agreement amongst Smart City visionaries that digital technologies are prerequisites for improving the quality of life in cities, reducing resource consumption for effective urban governance and sustainable urban futures. Against this background, nearly every city wants to be 'smart' in this sense, and nearly every city relies on techno-managerial solutions $[4,8,12]$. Critical responses to Smart City narratives are not directed against digitalisation per se, but question publicprivate partnerships as the profit-driven interests of ICT corporations, which are beyond the reaches of the democratic legitimation that urban governments represent.

The point of departure for most Smart City implementations is not urban renewal, nor any kind of social or ecological crisis, but the technological feasibility of digitalisation-that is, the implementations are based on the services offered by the companies. Vanolo has described this kind of smart mentality as "an urban imaginary combining the concept of 'green cities' with technological futurism and giving a name to techno-centric visions of the city of tomorrow" [31] (p. 894).

Beyond the general idea of digitisation, the term 'Smart City' is not associated with one definition but with multiple urban functions and infrastructures. As Clark describes, "[s]mart cities are difficult to define. Almost every discussion of smart cities begins with an effort to define the term or to assert that no definition is possible or necessary ... it is a 'fuzzy concept'" [10] (p. 2). Similarly, Luque-Ayala and Marvin state that, "[s]ince its inception, the smart city has been a vague and nebulous concept" [11] (p. 14). The dominant narratives, however, promise the improvement of mobility, housing, waste management, resource efficiency and many other areas of daily urban life. However, increasing digitalisation does not change urban functions and necessities-it advances only the dynamics of connectivity and control with respect to infrastructures. Smart Cities' promises to modernise and renew urban life are often not demand-driven but are based on the services offered by ICT companies such as IBM, Cisco, Hitachi, or Siemens. Therefore, the implementations do not respond to the most pressing needs of the majority of urban citizens.

The Smart City does not fight socio-economic, socio-cultural or ecological injustice in cities and even has counterproductive effects on ecological sustainability ('rebound effects'). Swyngedouw and Kaika have claimed that 'sustainability' became the empty signifier that referred generically to the phantasmagoric vision of a world in which people, the economy and the environment could happily and lovingly interact in mutually supportive, cohesive and historically reproducible manners, mediated by increasingly 'smart' technologies that would benignly micro-engineer the delicate balance between humans and nature. The term 'sustainability' (which has neither intellectual coherence nor political substance) has now become hegemonically engrained and consensually accepted as the normative ideal that, with the proper techno-managerial devices in place, might not only render our urban ecological predicament bearable but also permit civilisation as we know it to continue a while longer without engendering significant socio-political change [32].

Smart City narratives are universal(ising) stories that neglect the "diverse histories, cultures and political economies and variegated forms of capitalism that shape patterns of urban and economic development and the relationship between state, market and society" [2] (p. 133) [8,33]. From its beginning, urban digitalisation was supported by changes in urban policy, the turn towards governance structures and entrepreneurial principles with the effect that, by now, most urban governments manage 'their' cities like corporations. In the global competition to win over the largest companies, the most modern image and the smartest citizens, cities try to attract attention through stories of digital innovation. With 
this strategy, neoliberal local government ideas meet the profit-oriented interests of ICT companies and result in financialised urban development following corporate management principles [34]. Moreover, digital urban infrastructures are linked to entrepreneurial urban policy that promotes the privatisation of public tasks and infrastructures, and thus supports the outsourcing to private actors of activities previously carried out by public authorities.

\subsection{Entrepreneurial Urbanisation}

Entrepreneurial urban governance predates smart urbanism. Neoliberalism has created new forms of governance that favours corporate capital and the upper classes in shaping urban processes [1]. While cities, during the post-war decades, had a managerial role in organising and (re)distributing services of interest by the welfare state only, the neoliberal turn has changed the role of cities and "urban governance has moved more (... ) into line with the naked requirements of capital accumulation" [9] (p. 15). Neoliberal urbanisation processes aim to lure global surplus capital. Therefore, they address certain external economic actors, such as companies or high-income population groups, and are characterised by speculative large-scale projects framed within strategic planning frameworks that compare to short-term business plans for the city, paving the way for an engagement of non-state actors.

This is paired with downscaling processes of power from the nation state to the local urban scale. Cities no longer primarily have the function of a state administrative apparatus but act as corporations, considering themselves competitors for globally active capital. In order "to control multinational money flows, ( . . ) investment increasingly takes the form of a negotiation between international finance capital and local powers doing the best they can to maximise the attractiveness of the local site as a lure for capitalist development" [9] (p. 5).

The hegemonic shift from managerialism to entrepreneurialism [9] in most European and North American cities since the late 1980s is expressed both in terms of urban governing processes (from government to governance) and urban policy strategies. The entrepreneurial mode of urban governance implies a broader coalition of forces that reorganises urban life and is characterised by a transfer of market and competition mechanisms to the internal regulation of urban processes that were once distinctive to market actors. This is expressed through the implementation of business management models, the creation of competitive relationships, profit motivation, risk-taking and city branding, as well as public-private partnerships and the privatisation of public companies and infrastructures (such as public utilities, mobility and waste management) [9,35,36]. All aspects of politics tend to be subordinated to the overarching goal of improving place attractiveness-and hence competitiveness [35]. The increasing emphasis on the quality of life and the sense of place is expressed in urbanisation processes through strategies of urban regeneration that focus on the symbolic and physical upgrading of the urban environment [9]. This is done, on the one hand, through investment in mobility, communications and provision of adequate office spaces, and on the other hand, in boosting the symbolic image of the city.

Once a city has positioned itself on the map to attract companies, affluent consumers and high-income households, the entire population will supposedly benefit from trickledown effects, or so predicts the neoliberal rationale. Accordingly, social and welfare investments are considered as an expected outcome of economic performances and are conditioned by it $[9,35]$. Thus, entrepreneurial urbanisation follows a supply-oriented economic logic that is based on potentialities-as opposed to rationally planned and coordinated development based on existing demands. The speculative risk of these publicprivate partnership ventures, however, is not shared equally: the private sector takes the benefit while the public sector assumes the risk [9]. Consequently, local subsidies flow in favour of capital accumulation, and thus prioritise wealthy, international consumers and corporations at the expense of meeting local needs, provision for the poor, social welfare, redistribution and social justice. Or, in the words of Marcuse and Van Kempen: "development may mean profits for one, displacement for the other" [37] (p. 265). By 
focusing primarily on 'good business climate' and the needs of the upper and middle classes, neoliberal urbanisation processes tend to increase existing the inequalities and disparities in wealth and income and intensify the dynamics of impoverishment and disempowerment in the city $[9,35,38]$.

Investment in one place always results in disinvestment in other places. Thus, uneven geographical development is a structural element of capitalist urbanisation $[9,39]$. However, at the same time, capitalist urbanisation-temporarily-resolves problems of overaccumulation, since it fixes surplus capital, spatially embedding it in land. 'Fix' in this context holds a double meaning: first, to secure surplus capital in space, and, second, to fix a problem (capitalism's crisis tendencies) temporarily [40]. In other words: "Capitalism, we might say, is addicted to geographical expansion much as it is addicted to technological change and endless expansion through economic growth" [39] (p. 24).

Employing spatial and technological fixes, smart urban development strategies are leading to an "erosion of social rights" [40] (p. 365). With a focus on the quality of technology rather than of lives, techno-managerial systems reinforce socio-spatial injustice [9,41]. These dynamics can be well observed in respect to the uneven development processes provoked by targeted investments in smart districts and the subsequent disinvestment in others. These smart excesses in prospering neighbourhoods result in a lack of financial means to maintain basic public services in education, health, housing or mobility in 'ordinary' parts of the city [5]. As smart ICT innovations are predominantly luring investments to indicator-based goals [41], the disproportional attention results in increasing injustice and segregation within the entire city. Failing to "productively [ . . . ] satisfy social needs", smart, neoliberal urban development projects are "generally at the cost of considerable human suffering and massive environmental degradation" [38] (p. 4). Therefore, alternative policies and economies countering social and spatial divides are needed in order to deal with social and/or environmental problems and injustices.

\subsection{A Right to the City in the Context of Smart Urbanism}

The structural processes underlying smart urbanism reveal capitalist dynamics of the valorisation of urban space that Henry Lefebvre already observed in the late 1960s. In the course of these processes, powerful economic actors and the state shape urban space and infrastructures in ways that create and replicate social injustices. Similar to Lefebvre's outline, we observe that Smart City developments are reshaping cities according to the preferences of urban developers [3] and not according to the qualities of urban life and along local demands for socio-spatial justice-fuelling conflicts between the exchange value and use value of urban spaces and urban infrastructures [3]. Here, exchange value describes the quantifiable economic exchange as the urban is regarded as a product. In the words of Lefebvre, exchange value is determined by the "spaces bought and sold, the consumption of products, goods, places and signs" [3] (p. 86). Opposing such quantifiable measures, use value expresses the qualities of urban life. The appraisal of the urban as a liveable space strongly associates with Lefebvre's description of the city as an oeuvre-a work of art. Lefebvre's attention to the opposing forces of exchange and use value in urban dynamics is formulated as a critique of capitalist accumulation strategies dominating city developments and leads towards his proposal of the 'right to the city': "The right to the city cannot be conceived of as a simple visiting right or as a return to traditional cities. It can only be formulated as a transformed and renewed right to urban life. It does not matter whether the urban fabric encloses the countryside and what survives of peasant life, as long as the 'urban', place of encounter, priority of use value, inscription in space of a time promoted to the rank of a supreme resource among all resources, finds its morphological base and its practico-material realization" [3] (p. 158). Consequently, in order to guarantee the right to the city and qualities of urban life, Lefebvre promotes urban infrastructures as public and use value oriented rather than as profit generating for private parties.

Encouraging "an urban reality for 'users' and not for capitalist speculators, builders and technicians" [3] (p. 168), Lefebvre's proposed right to the city is "a superior form of 
rights: right to freedom, to individualization and socialization, to habitat and to inhabit. The right to the oeuvre, to participation and to appropriation (clearly distinct from the right to property), are implied in the right to the city" [3] (pp. 173-174). With regard to the arguments put forward in this paper, the rights to appropriation and participation become particularly relevant in the context of smart urban developments. Contrary to the usage of the terms as empty signifiers, Lefebvre refers to appropriation and participation as two emancipatory urban strategies that prioritise use value over exchange value. Creating coexistences and interventions in urban relations, the right to appropriation closely relates to the term 'integration'. Here, Lefebvre distances himself from the "obsessional theme, an aimless aspiration" of integration as a "social connotator" [3] (p. 145); rather, he foregrounds integration in relation to appropriation as a concept of social practices. The practices of appropriation not only use, employ or occupy already existing urban infrastructures but also strategically produce urban space in respect to its use value. Therefore, the right of appropriation is creating, fostering, negotiating the quality of life. Closely tied to the right of appropriation, Lefebvre addresses participation as another emancipatory spatial strategy concerning urban dynamics. Beyond the basic practices of community information or consultation, which Lefebvre addresses as mere 'self-management', the right to participation encompasses "the right to information", the right to use "multiple services", "the right of users to make known their ideas on the space and time of their activities in urban areas" [3] (p. 34).

These two emancipatory spatial strategies of appropriation and participation as part of the right to the city highlight that Lefebvre's conceptualisation of the capitalist city in the late 1960s has not lost its relevance in contemporary neoliberal, entrepreneurial urban contexts and Smart City developments, as the following discussion on smart urbanisation processes in Graz illustrates.

\section{Methodology: Interpreting Smart Urbanisation}

By using Smart City narratives and their developments in Graz, we illustrate the entrepreneurial mode of smart urbanism. The following Section 4 is partially based on the doctoral research by one of the co-authors [42]. Employing a transdisciplinary mixed methods approach, he examined sustainability strategies and actual policies at the intersection of housing, energy and mobility in the city of Graz and compared proposed measures of sustainability strategies to the status quo of policy making. In addition to the previous research focus on mobility management, the paper further engages with selected smart city developments in respect to waste management. Due to the pronounced coalition of ICT-oriented waste management corporations and the city government in Graz, this complementary sector of urban infrastructures further highlights new forms of strategic partnerships in the (smart) city of Graz. For the purpose of our argument, we draw upon selected documents such as official strategy documents on Smart City developments by the City of Graz [43], recent publications and public announcements of the City of Graz [44,45] and its municipal holding company [46], cooperating private companies [47,48] and the provincial government of Styria [49] as well as reports [50], local press and media coverage [51-53]. These sources have been compiled through a process of theoretical sampling [54] and analysed in respect to the categories deduced from the conceptual framework of critical smart-urbanism and neoliberal urbanisation literature. Their interpretation is based on the qualitative social science research approach of critical hermeneutics [55]. This interpretative approach grounds in the understanding that social reality is always mediated in and through language and thus can be examined as-and through - texts. According to critical hermeneutics, the interrogation of social realities follows a "hermeneutical circle" [55] (p. 37), which engages with the part and the whole. Moving between theory and practice allows us to deepen the overall understanding of the objective of study. In using this analytical approach, we follow Grossi and Pianezzi, who "suggest that only an interpretative circle that enriches meta-narratives of smart cities with the complexity of real cities, and interprets these cities in the light of the above 
theoretical explanations and conceptualizations may grasp the meaning of the smart city paradigm" [56] (p. 81).

\section{Smart City Graz: Who Cares for Waste and Mobility}

As a representative example of many Central European medium-sized cities, the Austrian city of Graz provides vivid examples of Smart City projects and urban governance in the context of entrepreneurial urbanism, including waste and mobility management. The second largest city in Austria, Graz counts 294,000 inhabitants [57] (642,000 within its agglomeration [58]). As the fastest growing metropolitan area in the country, the city faces particular challenges in its urban development [59].

One of the major avenues of urban development to address contemporary challenges of urbanisation is the local Smart City strategy 'I LIVE GRAZ_-smart people create their smart city', presented by the city of Graz in 2012. The document announces plans to establish Graz as a Smart City. With the ambition to achieve a high quality of urban life as well as a highly ranked innovation, technology and service centre, the strategy aims to establish an energyefficient, resource saving, zero-emission and compact city focusing on innovative urban systems and technologies. Five key fields of action for a liveable and sustainable city-the 'Smart City Graz' - are addressed. These include urban planning, citizen participation and awareness-raising, economic incentives, legal framework and organisational development. The fields pursue goals such as densification, land recycling, mixed use development, the compact city, increased participation and the creation of attractive public green and open spaces. A roadmap envisions this transformation by first constructing Smart City quarters as well as subsequently transforming districts and finally turning the whole city smart [43]. Since 2017, two Smart City quarters, entitled 'My Smart City Graz' and 'Reininghaus', are being built. These developments are scheduled to be completed in 2025 [60]. As the whole city is planned to become a Smart City, the following discussion addresses the two exemplary sectors of waste and mobility to highlight developments on the city level.

Urban developments in the fields of waste and mobility management illustrate congruences as well as divergences of Smart City narratives and urban governance in practice. In the city of Graz, the privatisation of municipal services already started in 1960 with the foundation of a public limited company (Stadtwerke $A G$ ), incorporating the business divisions transport, electricity, gas, district heating and water. Successively, other fields were included, which made the company the provider of services in almost every important area of urban infrastructure. In 2010, this strategic shift was completed with the establishment of Holding Graz Kommunale Dienstleistungen $\mathrm{GmbH}$. This holding company now manages the provision of public services for the city of Graz by taking care of the-previously municipal—tasks of mobility, water management, urban space and waste management within the framework of financing and service contracts. All market-economy business areas of the city are managed in separate companies with different shareholdings. Smart City initiatives are amongst the landmark projects of Holding Graz because they focus on new urban technologies, especially in the areas of mobility and energy but also in all other municipal economic areas, such as waste management [46]. However, these Smart City initiatives by Holding Graz deviate at times from urban planning regulations of the City of Graz, particularly when it comes to citizens' participation.

Compared to other Austrian cities, Graz has a relatively long tradition when it comes to citizen participation in urban planning. As early as 1970, a citizens' initiative was formed that successfully rebelled against the construction of an inner urban highway. These protests led to comprehensive citizen participation schemes in regard to the city's road planning in 1975 [61]. In 1974, the Office for Citizens' Initiatives (today: Department for Citizen Participation) was installed in the Graz City Council. The office was tasked with organising and channelling citizen participation and henceforth implemented numerous activities and projects for participatory urban development [62]. In 2014, the city council implemented the 'Guidelines for Citizen Participation', which binds the municipal authorities to implement specific participatory procedures in urban development processes. Conse- 
quently, these guidelines assure specific groups to recheck, in cases where the city does not yet plan participation, whether citizen participation can be implemented despite previous considerations [59].

\subsection{Smart Waste Management in Graz}

The Smart City Graz strategy relates a smartness that is 'fit for the future', with sustainability in the sense of integrated material cycles. It entails two different approaches with regard to waste management, which summarise under the "vision ecology" and the "vision supply and disposal" categories [43] (p. 16, 19). In the first, Graz is simply envisioned as a "waste-free" [43] (p. 19) city, without further qualification. The second vision-on supply and disposal—provides a more substantial framing of waste-related sustainability problems. It ascribes Graz to the circular economy agenda and envisions the city's urban society in 2050 as a "recycling society" [43] (p. 19) that is guided by the overall principle of waste prevention and minimal packaging with reference to close(d) local material flow circuits. However, it adheres to the polluter pays principle focused on consumers (in contrast to frameworks, such as extended producer responsibility, that emphasise the responsibility of industries [63]) and also proclaims as the overall goal that the city of Graz has to become 'waste-free' [43].

In contrast to this vision of close(d) local material and energy circuits, the practical efforts of municipal solid waste management (MSWM) in Graz are mainly focused on the efficient collection, transfer and disposal of solid wastes. This is not surprising, because MSWM has, historically, evolved as a technocratic effort by the state administrative apparatus to control pollution [64] and is generally geared towards cleanliness and the disposability of waste as nuisance-the focus is on how to get rid of it instead of asking where it is coming from [65]. Such processes are also visible in Graz, where MSWM services are provided by Graz Abfallwirtschaft, another separate shareholding company of Holding Graz. Graz Abfallwirtschaft is responsible for residual waste collection and operates a mechanical waste processing plant and recycling centre. Together with the regional waste management service company Saubermacher, it formed the public-private partnership company Servus Abfall Dienstleisungs GmbH in 2002 [46]. Servus positions itself as a regional waste management and circular economy service provider that aims to "develop and digitalise waste management and circular economy solutions" [47].

In Graz, smart waste management solutions have so far mainly translated into smart disposal infrastructures and technologies. This includes "digital trash cans" [66,67] in public spaces, which transmit their filling levels to prevent spilling. Aiming to provide efficient waste collection, these online trash cans are supposed to reduce $\mathrm{CO}_{2}$ emissions. One widely spread and internationally well-known example of such smart disposal infrastructures is the so-called BigBelly, which has been installed in Graz as well [51]. It compacts inserted wastes in order to increase its filling capacity. Newer models are also able to communicate with public trash can users. These kinds of "speaking trash cans" [52] constitute the latest avenue of smart disposal technologies geared to communicate with, and potentially also discipline, users in order to prevent misplaced types of waste and littering. The 'Abfall App' (waste app) of Graz Abfallwirtschaft represents another channel, through which citizens are informed about waste collection and segregation to influence their individual disposal behaviour.

A more integrated and comprehensive smart waste management solution developed and promoted for Graz by the waste management service company Saubermacher is the so-called "Waste Management 4.0" [48]. This "Smart Waste Collection Platform" aims at optimising the waste disposal and collection system in line with real time data on waste generation amounts and composition: "[T]he 'smart waste' approach is supported by sensors and scanners in the waste collection vehicles themselves, which visually detect when something wrong ends up in the cart compactor. For the first time, citizens will also receive direct feedback on their own separation behaviour on their end devices" [48]. Saubermacher is well aware about the sensitivity of this individualised data and rules 
out its use for the penalisation of wrong disposal behaviour [53]. However, it is central to interrogate the implications of the availability of this data, as it potentially leads to (arbitrary) indicators imbued by power relations and socio-spatial inequalities in the city. The Holding Graz is now already refusing to collect waste from housing complexes inhabited by marginalised social groups due to their supposed disposal-misbehaviour [68].

The Smart City strategy of Graz envisions a 'waste-free' 'recycling society' based on local material flow circuits. In contrast to this vision, techno-managerial solutions under the rubric of 'Waste Management 4.0' and 'Smart Waste Management' [66] are almost exclusively focused on cleanliness, increasing collection and disposal efficiency, making its inner-city recycling plant invisible and inaudible by means of a 10-metre-high shielding wall [69], 'smart' awareness-raising and the disciplining of individuals in how to dispose of their waste. As such, they may provide apt opportunities for the investment of ICT venture capital backed by the local state. However, they neither address the pressing socioecological problem of constantly rising waste quantities nor the increasing complexity of the material compositions of wasted things. They address waste and wasting as structural issues, not behavioural ones [70]. Moreover, they leave aside the majority of waste material generated during production, distribution and provision of goods and services and focus merely on the tiny fraction that is post-consumption waste [71]. These techno-managerial solutions merely represent technological fixes that reduce the 'waste problem' to the managerial problem of recyclables ending up in residual waste fractions [48] as well as misplaced types of waste that contaminate organic waste fractions [52]—or littering and cleanliness more generally. Thus, the 'smart waste' approach by Holding Graz, Saubermacher and Servus is a particularly instructive example of digital technologies and infrastructures that are geared towards the monitoring, control and also disciplining of citizens instead of active inclusion and participation in the way urban citizens handle waste-and are enabled to "waste differently" [72] (see [68] for Graz).

\subsection{Smart Mobility in Graz}

The Smart City Graz strategy also focuses on smart sustainable mobility. By providing a functional mix and compact urban structures that facilitate sustainable modes of mobilitythat is, walking, cycling and public transport-the strategy aims to decrease the share of motorised individual transport. A corresponding action plan provides measures such as the expansion of the public transport network; ICT-supported information and route planning for public transport; extension of the bicycle route network, bicycle parking spaces and service points; bike and car sharing offers; or the adaption of street space to the envisioned shift of the modal split [43]. According to the strategy, a substantial part of the space currently occupied by motorised individual transport will be regained for public use and green spaces. It is stated that the street space required can be reduced to $25 \%$ of the present occupied space [43].

This mobility vision stands in harsh contrast to the actual developments. In the spring of 2020, the first residents settled in the new Smart City quarters. While the parking garages for cars were already in place, the tram lines in both quarters are only planned to be in operation by the end of 2021 [73]. In the 'My Smart City Graz' quarter, the bicycle path is planned to be completed by 2022 [44]. All of this is happening against the backdrop of the long-term experience that everyday mobility behaviour is shaped at the time people move into a new home [74]. The well-intended free public transport ticket for inhabitants during their first year of residence is hereby reduced to the absurd [60,73]. Moreover, the City of Graz plans to build a railway underpass that enables motorised individual transport to access the city centre directly from the Smart City quarter 'Reininghaus'. Due to space constraints, the combined bicycle path and sidewalk are only three metres wide for both directions, which presents a bottleneck for bicyclists and increases the hazard of accidents with pedestrians [49]. This comfortable access to the city for motorised individual transport creates an incentive to take the car instead of other modes of transport. Thus, the underpass privileges car owners in appropriating comfortable access and significant amounts of space 
while, at the same time, impairing the quality of life for all residents living along this new road link due to increased noise, pollution and risk of accidents. Therefore, these plans contradict the strategy of preferred sustainable modes of mobility, which includes the ambition to reduce the number of cars in the city centre.

Why is the City of Graz even considering such a project? The reason is model calculations of the expected development of motorised individual transport, which are based on the emerging dwellings and businesses in the new Smart City quarter [49]. Opposing the vision of sustainable mobility as formulated in the strategy, prescribed mobility patterns will continue to persist and therefore only very slowly shift towards the strategy's original goals. In the course of the environmental impact study, numerous complaints criticised the calculation method and the impact on air pollution, noise, safety, soil sealing and energy consumption [49]. Thus, the means of participation were reduced to the ability to file a complaint. Nevertheless, the report was positive, arguing that all regulations and calculation methods are according to the current existing law. Ironically, even a positive impact on the emissions has been identified, as, due to the increasing use of electric cars, the emissions of cars are expected to decrease by $7 \%$ in the period covered [49]. Consequently, ambitious strategies also have to impact the existing law to enable the foundation for sustainable change towards their goals.

Another aspect is the prioritisation of such car-focused infrastructure projects over the postponed extension of the tram system. While the local government persistently argued that there is no money to extend the tram system to two major existing residential districts of the city and while all the corresponding plans already have been present since decades, it pursues costly road infrastructure projects favouring prestigious Smart City developments against any sense of sustainable mobility.

\section{Discussion}

Urban governance in the city of Graz and its municipal holding company for public services illustrate structural conditions corresponding to the logic of entrepreneurial urbanisation. Of the ambitious and comprehensive goals in the Smart City strategy [43], only very limited aspects are implemented-merely those that are oriented towards the privatisation of urban infrastructures and services and the prevalence of market mechanisms. The prioritisation of exchange value over use value - of capital accumulation and 'profit making' in conjunction with private ventures into ICT—explains why Smart City innovations in Graz generally fail to address the prevailing social and ecological challenges related to ongoing processes of urbanisation. They do not structurally solve the big issues regarding urban waste and mobility because they primarily strive to meet entrepreneurial demands. This observation is by no means specific to Graz. On the contrary, these problems can be found in the results of numerous case studies on other European and North American (smart) cities: Bike sharing systems, for example, benefit the privileged and help little to increase cycling as a means for sustainable transport while they further advance unjust tendencies to privatise public urban space [14]. Beyond sustainable transportation, Yigitcanlar and Kamruzzaman stress that there is no strong evidence on a positive correlation between technology adoption and sustainable outcomes after investigating various UK cities and that so far, smart city strategies have failed to push sustainability beyond rhetorics [15]. Martin, Evans and Karvonen come to a similar conclusion after reviewing several case studies on Smart Cities in Europe and the US: They point to the fact that smart city initiatives in practice result in rather unsustainable forms of economic growth and consumerist cultures, while neglecting questions of social and environmental justice [16]. In this sense, digital smartness loses its appeal as innovative and emancipatory. Instead, the prevailing modes of urban development relying on neoliberal ideologies and economic structures intensify. Angelidou exclaims that "the current dominance of supply-driven smart city solutions often results in smart city strategies that are dis-connected from their social context and fail to tackle a city's problems in a cohesive way" [17] (p. 104). 
Similar to other Smart City projects in Europe and North America (summarised in, e.g., $[16,18,19])$, there are clear indications for a dominance of 'entrepreneurial' and 'service user' modes of the public in Graz intensifying silo-thinking-not only in functional, but also in participatory terms (see below). Moreover, MSWM in Graz reflects both the privatisation of public services in the course of entrepreneurial urbanisation as well as the proliferation and implementation of techno-managerial solutions framed under the Smart City rubric. The vision of close(d) material cycles and waste reduction (or avoidance) put forward in the Smart City Graz strategy contradicts the practical and structural effects of privatisation, public-private partnerships and the techno-managerial reframing of problems related to urban waste management. Although there are different ways of understanding what waste actually is and what a 'waste-free' city could look like, practical MSWM implementations focus predominantly on misdirected residual waste or recyclables as a socio-spatially differentiated problem of the efficiency of disposal and recycling systems. In contrast, initiatives such as Repair Cafés or the system of "Re-Use Boxes" developed in Graz by the NGO ARGE Abfallvermeidung (Working Group on Waste Prevention) [50] directly address the potential use value of waste. They are complemented by local businesses focused on repair and maintenance as well as upcoming packaging-free shops. Although the City of Graz is in principle supporting these actually smart and sustainable initiatives and businesses (also financially), its Smart City investments and strategic developments in the field of waste management are not systematically linked to them on a structural level. The supposed waste-management strategies in the Smart City reduce the waste-related problems to techno-managerial problems of collection efficiency and disposal practices. Thus, it concentrates on the supply of profit-generating services provided by the private company Saubermacher. This prioritisation of waste collection, disposal and recycling infrastructure as well as the accounts of efficiency are not only questionable in terms of (un)sustainability. It also represents a structural disinvestment from the labour-intensive reuse, repair and upcycling sector, in which mostly marginalised social groups are employed, who face discrimination on the labour market [75]. The privatisation of public services and public-private partnerships in MSWM are shoring up the underlying misconception and mistreatment of the urban problems related to waste. The implementation does not lie directly within the hands of the City of Graz but is carried out by subsidiaries of the municipal holding company. Accordingly, companies such as Servus do not deal with structural issues, such as how production processes and material cycles function throughout the city, how packaging materials enter the market or how people are enabled to waste and recycle differently [68]. On the contrary, these profitoriented service companies are primarily interested in how waste or residual materials end up with them and can be channelled as efficiently and lucratively as possible, thereby sequestering resources and subverting or even thwarting the democratic control and participation that has to be the linchpin of any just and sustainable city. Similar processes can also be observed in the sector of mobility.

The Smart City strategy of Graz [43] was developed in a broad process that also included consultation with experts from various areas. Accordingly, the city aims to evolve into a compact and multifunctional city that facilitates sustainable mobility practices. Despite these ambitious goals, the implementation of this strategy by politics and the administration is ultimately subject to planning tools based on the perpetuation of the status quo: scenarios and model calculations project additional car traffic generated by the newly created housing districts and determine that, consequently, high-level car access to the city centre will be required. Other forms of sustainable mobility - that are promoted in the Smart City strategy - are eventually given secondary priority according to this logic. First, decisions are made about a car underpass and the remaining public areas are allocated to active forms of mobility only afterwards. Furthermore, money is spent for this Smart City infrastructure instead of long-postponed tram lines to existing districts. Instead of focusing development primarily on Smart City districts, the provision of basic services for the whole population is actually smart [20]. This represents yet another example of 
socio-spatial injustice and "sustained unsustainability" [76] (p. 1). The emerging gaps of the public transport and bicycle networks are often closed at a much later stage. However, once the new residents of the Smart City neighbourhoods have already moved in and adapted their mobility patterns to the advantages of driving a car, it is difficult to change their behaviour [74]. To address this with smart measures, the City of Graz obligated developers, through the means of town planning agreements, to install information screens with departure times of public transport in the lobbies of the newly built residential buildings in the Smart City quarters. While this generally sounds like a reasonable solution to increase the comfort of using public transport [77], this actually represents a technological fix to a problem that was created in the first place. Moreover, it is another example of socio-spatial inequality, as information screens only serve the inhabitants of the smart city, instead of investing in a system that serves the whole city, as for example in Paris [78]. The same tokenism also occurred in regard to institutionalised and official modes of citizen participation in mobility planning. In the case of the discussed railway underpass, citizens were merely informed via a poster exhibition and means of participation were reduced to legal objections within the obligatory environmental impact assessment [79].

These supposedly democratising guidelines implemented at the administrative level, however, do not (yet) apply to the holding company at all. In fact, the governance structures that carry out major urban developments in Graz are not obliged to implement any formal means of participation. Usually, urban development planning should take place in the responsible administrative units of the City of Graz-the municipal holding company is the executive body. However, it happens frequently that Holding Graz performs or orders internal feasibility studies for costly projects that are not integrated into the strategic guiding principles of the city. Due to non-transparent decision-making processes related to the privatised company setup of Holding Graz, these projects receive well-funded budgets, which are used to influence the public opinion by broad media campaigns. At the same time the responsible administrative municipal units often are not involved in the commissioning and preparation of the studies. Consequentially, long-term infrastructure decisions are influenced by specific interest groups in their own favour, while transparency, participation and integration in these processes come up short [44] (see Gohari et al. [21] for similar insights drawn from three Norwegian cities and Smigiel $[80,81]$ for further cities in Austria and Italy).

\section{Conclusions}

In order to address the prevailing social and ecological challenges of urbanisation processes, citizen participation should not be constrained to narrowly predefined frameworks of passivity and pseudo-participation. Instead, it should encourage participation in and appropriation of the city in a Lefebvrian understanding that is closely linked to integration [3]. It goes without saying that this kind of participation encompasses more than information and could incite a political revolution: a practice that is "oriented towards social needs and democratic control of the State and self-management" [3] (p. 180). A really smart city - in this sense - cares for and actively enables appropriation by its inhabitants. In the examples drawn from Graz, this would include spatial and social practices to discard and reuse waste differently and to move within the city with public or non-motorised forms of transport.

Smart Cities, in Graz and elsewhere, are to be considered as spatial and technological fixes within an entrepreneurial logic of capitalist urbanisation. These place-specific projects become the "focus of public and political attention [and] divert concern and even resources from the broader problems" concerning the city (or region) "as a whole" [9] (p. 8). They may be smart in the rationale of market-oriented digitalisation and city management strategies, but, from a 'right to the city' perspective, they leave many uncomfortable realities unaddressed

Smart City strategies promote "corporate storytelling" [8] in smart urbanism narratives that claim to improve the quality of life of all its inhabitants and address the ecological 
and climate crises. They focus on technological feasibility and on services offered by ICT companies, thereby reducing smartness to digitalisation. Yet, the demand-oriented framing of policy documents and development strategies-supposedly following the needs of all citizens and the environment-seems to vanish within the implementation process. Unlike the strategical vision, the actual urban development projects are supply-side oriented: they pursue the profit interests of industries and investors-subsidised by the public sector that yearns for the promised trickle-down effects on the whole city and all its citizens [9]. Dominant Smart City narratives "assume certain users behaving in certain ways - at the expense of other users or behaviours. [ ... ] [M]embers of the population who do not "fit" the idea of the assumed user; for example children, the elderly, those with disabilities, non-native speakers or those less comfortable using certain technologies" [82] (p. 18-19, 22) are (once more) overlooked and put at a disadvantage (see also [12]). In fact, the implementation of the strategies reproduces—or even intensifies—socio-spatial and ecological inequalities and injustices by favouring (and investing in) specific spaces for specific people: the affluent (car-driving) middle class that is desired to settle in the smart, clean and orderly new city quarters. Consequently, people's rights and roles in smart cities vary, as do the forms and levels of participation $[19,83]$.

Smart urbanism-in all its facets-is a typical form of entrepreneurial urbanisation. It does not fix any of the present crises in housing, mobility and waste management, nor does it tackle questions of environmental and social justice. It attempts to fix, however, the limits to capitalism's growth by digitalisation. An actually smart city, however, cares for sustainable modes of everyday life on a structural level-it cares for the needs and the future of all of its inhabitants. It thus takes urban problems that actually need to be solved as its starting point. It is oriented towards use values (rather than exchange values), demand (rather than supply) and the everyday needs of inhabitants (rather than vested economic interests and capital accumulation). This vision of urban life enables participation and appropriation and challenges socio-spatial injustice on a structural level.

Our argument critically refers to anticipated and problematic effects of the smart city developments that are currently taking place in Graz and elsewhere. Yet, we would like to point out some limitations, e.g., that the actual implications in terms of a (more) just and sustainable city can only be assessed in the long run. What is more, we suggest going beyond the frequently expressed criticism and concern regarding smartification of cities, the production, collection and extraction of personal data, the control of urban life and citizens according to (arbitrary) digital indicators and algorithms, as well as the question of data protection $[13,84]$. In this sense, we argue for an in-depth analysis of the (un)collected data in terms of (in)justice, to which we have not given attention in this article. We assume that Big Data and the indicators developed from it reinforce structural sociospatial discrimination and injustices [85-87], for the (non)collection of certain data often obscures the underlying algorithmic violence that "works through data-driven planning technologies to depoliticize and leverage power while further entrenching racism and inequality" [88] (p. 200) [89].

For this contribution, we have applied 'participation' in a Lefebvrian sense and thus did not engage with widespread participation formats in Smart Cities, which, again, mostly follow the logics of the neoliberal and entrepreneurial city. Just because digital technologies enable sociodigital connectivities, they do not automatically promote participation and democratic ideals. Technology-enabled forms of public engagement often reduce participation to a superficial level or "token participation" [90,91]. Using the example of Dublin City's Smart City strategies and initiatives, Cardullo \& Kitchin show that only a few projects correspond to an actual empowerment of citizens, while most initiatives rely on a "neoliberal citizenship" and an "entrepreneurial self" in the context of marketisation and privatisation [19]. Moreover, digital participation increasingly replaces established forms of citizen participation. Because of this, some cities in Canada, for example, return to traditional forms of citizen participation in the development of smart cities, such as citizens' meetings, round tables and workshops [92]. 
This paper and our illustration of smart developments in the city of Graz, Lefebvre's right to the city serves as an important normative horizon to envision an alternative to technocapitalist urbanisation. This framework is grounded on a fundamental structural critique of the entrepreneurial city. It prioritises needs and enables participation and appropriation [3]. Furthermore, the right to the city is "a transformed and renewed right to urban life [in which] the 'urban', place of encounter, priority of use value, inscription in space of a time [are] promoted to the rank of a supreme resource among all resources" [3] (p. 158). Such a vision also includes-but is not limited to-digitalisation. However, digitalisation not as means to pursue corporate interests collecting and extracting data, but in a democratic and open(-source) sense of transparency and solidarity inviting the use and appropriation by all citizens. It is a vision in which new technologies are used in a participatory and cooperative way rather than for increasing efficiency and control. This vision comprises an "informational right to the city" [13] beyond Google's power over geographical information on the one hand and explores actual variations of platform municipalism [93] on the other. A smart right to the city would mean that the city as a whole has to be considered, prioritising structural disadvantages and social justice: "This involves valuing specific civic knowledge, character, issues, and resources, down to the hyper-local dimension, and using these to drive and direct innovation. It means informing "smart" from within the city, rather than relying on an "in-the-box" product-based version of it." [94] (p. 68). For the example of waste and wasting, it would mean to invest into digital technologies only if they are primarily geared to support (and being appropriated by) existing initiatives for reuse, repair and waste prevention as well as the active inclusion and participation of citizens (in changing the ways they produce and use things in the city). Accordingly, we emphasise the right to participation and appropriation in regard to current processes of digital urbanisation and we argue - with respect to the right to the city-for a fundamental discussion about the processing and valorisation of data and the privatisation of digital urbanisation processes. After all, digital developments should be oriented to existing needs of all inhabitants and not merely to the supply—and the profit interests—of multinational corporations. This is what makes them innovative, what makes them a sustainable and just alternative to entrepreneurial technocapitalist urban developments.

Author Contributions: Conceptualization, A.S. and R.S.; formal analysis, A.S., N.S. and R.S.; investigation, writing—original draft preparation and writing—review and editing, A.S., R.S., N.S., B.H., T.H. and B.G.; funding acquisition, A.S. All authors have read and agreed to the published version of the manuscript.

Funding: Part of the research received funding from the Elisabeth-List Fellowship, University of Graz.

Institutional Review Board Statement: Not applicable.

Informed Consent Statement: Not applicable.

Conflicts of Interest: The authors declare no conflict of interest.

\section{References}

1. Harvey, D. The right to the city. New Left Rev. 2008, 53, 23-40.

2. Cardullo, P.; Di Feliciantonio, C.; Kitchin, R. Prelims. In The Right to the Smart City; Emerald Publishing: Bingley, UK, 2019; pp. 1-14.

3. Lefebvre, H. Writings on Cities; Blackwell Publishing: Oxford, UK, 1996.

4. Hollands, R.G. Will the real smart city please stand up? City 2008, 12, 303-320. [CrossRef]

5. Hollands, R.G. Critical interventions into the corporate smart city. Camb. J. Reg. Econ. Soc. 2014, 8, 61-77. [CrossRef]

6. Kummitha, R.K.R. Entrepreneurial urbanism and technological panacea: Why smart city planning needs to go beyond corporate visioning? Technol. Forecast. Soc. Chang. 2018, 137, 330-339. [CrossRef]

7. Levenda, A.M. Thinking critically about smart city experimentation: Entrepreneurialism and responsibilization in urban living labs. Local Environ. 2017, 24, 565-579. [CrossRef]

8. Söderström, O.; Paasche, T.; Klauser, F. Smart cities as corporate storytelling. City 2014, 18, 307-320. [CrossRef]

9. Harvey, D. From managerialism to entrepreneurialism: The transformation in urban governance in late capitalism. Geogr. Ann. Ser. B 1989, 71, 3-17. [CrossRef] 
10. Clark, J. Uneven Innovation. The Work of Smart Cities; Columbia University Press: New York, NY, USA, 2020.

11. Luque-Ayala, A.; Marvin, S. Urban Operating System. Producing the Computational City; MIT Press: Cambridge, MA, USA, 2020.

12. Strüver, A.; Bauriedl, S. Smart city narratives and narrating smart urbanism. In Exploring the Spatiality of the City across Cultural Texts: Narrating Spaces, Reading Urbanity; Kindermann, M., Rohleder, R., Eds.; Palgrave Macmillan: London, UK, 2020; pp. 185-204.

13. Shaw, J.; Graham, M. An informational right to the city? Code, content, control, and the urbanization of information. Antipode 2017, 49, 907-927. [CrossRef]

14. Medard de Chadron, C. The contradictions of bike-share benefits, purposes and outcomes. Transp. Res. Part A Policy Pract. 2019, 121, 401-419. [CrossRef]

15. Yigitcanlar, T.; Kamruzzaman, M. Does smart city policy lead to sustainability of cities? Land Use Policy 2018, 73, 49-58. [CrossRef]

16. Martin, C.J.; Evans, J.; Karvonen, A. Smart and sustainable? Five tensions in the visions and practices of the smart-sustainable city in Europe and North America. Technol. Forecast. Soc. Chang. 2018, 133, 269-278. [CrossRef]

17. Angelidou, M. Smart cities: A conjuncture of four forces. Cities 2015, 47, 95-106. [CrossRef]

18. Cowley, R.; Joss, S.; Dayot, Y. The smart city and its publics: Insights from across six UK cities. Urban Res. Pract. 2017, 11, 53-77. [CrossRef]

19. Cardullo, P.; Kitchin, R. Being a "citizen" in the smart city: Up and down the scaffold of smart citizen participation in Dublin, Ireland. GeoJournal 2019, 84, 1-34. [CrossRef]

20. March, H.; Ribera-Fumaz, R. Smart contradictions: The politics of making Barcelona a self-sufficient city. Eur. Urban Reg. Stud. 2014, 23, 816-830. [CrossRef]

21. Gohari, S.; Ahlers, D.; Nielsen, B.F.; Junker, E. The governance approach of smart city initiatives. Evidence from Trondheim, Bergen, and Bodø. Infrastructures 2020, 5, 31. [CrossRef]

22. Gandy, M. Cyborg urbanization: Complexity and monstrosity in the contemporary city. Int. J. Urban Reg. Res. 2005, 29, 26-49. [CrossRef]

23. Graham, S.; Marvin, S. Planning cyber-cities? Integrating telecommunications into urban planning. Town Plan. Rev. 1999, 70, 89-114. [CrossRef]

24. Barns, S. Negotiating the platform pivot: From participatory digital ecosystems to infrastructures of everyday life. Geogr. Compass 2019, 13, e12464. [CrossRef]

25. Barns, S. Platform Urbanism. Negotiating Platform Ecosystems in Connected Cities; Palgrave Macmillan: Singapore, 2020. Available online: https:/ / www.researchgate.net/publication/338321662_Platform_Urbanism_Negotiating_Platform_Ecosystems_ in_Connected_Cities (accessed on 1 July 2021).

26. Hodson, M.; Kasmire, J.; McMeekin, A.; Stehlin, J.G.; Ward, K. Urban Platforms and the Future City. Transformations in Infrastructure, Governance, Knowledge and Everyday Life; Routledge: London, UK, 2021.

27. Sadowski, J. Cyberspace and cityscapes: On the emergence of platform urbanism. Urban Geogr. 2020, 41, 448-452. [CrossRef]

28. Lee, A.; MacKenzie, A.; Smith, G.; Box, P. Mapping platform urbanism: Charting the nuance of the platform pivot. Urban Plan. 2020, 5, 116-128. [CrossRef]

29. Brenner, N. Implosions/Explosions: Towards a Study of Planetary Urbanization; JOVIS Publishers: Berlin, Germany, 2014.

30. Marvin, S.; Luque-Ayala, A.; McFarlane, C. Smart Urbanism: Utopian Vision or False Dawn? Routledge: London, UK, 2015.

31. Vanolo, A. Smartmentality: The smart city as disciplinary strategy. Urban Stud. 2013, 51, 883-898. [CrossRef]

32. Swyngedouw, E.; Kaika, M. Urban political ecology. Great promises, deadlock ... and new beginnings? Doc. Anal. Geogr. 2014, $60,459-481$.

33. Joss, S.; Sengers, F.; Schraven, D.; Caprotti, F.; Dayot, Y. The smart city as global discourse: Storylines and critical junctures across 27 cities. J. Urban Technol. 2019, 26, 3-34. [CrossRef]

34. Peck, J.; Theodore, N.; Brenner, N. Neoliberal urbanism: Models, moments, mutations. SAIS Rev. 2009, 1, 49-66. [CrossRef]

35. Schipper, S. Von der unternehmerischen Stadt zum Recht auf Stadt. Emanzipation 2013, 3, 21-34.

36. Schipper, S. Die unternehmerische Stadt. In Handbuch Kritische Stadtgeographie, 3rd ed.; Belina, B., Naumann, M., Strüver, A., Eds.; Westfälisches Dampfboot: Münster, Germany, 2018; pp. 147-152.

37. Marcuse, P.; van Kempen, R. Conclusion: A changed spatial order. In Globalizing Cities: A New Spatial Order? Blackwell Publishing: Oxford, UK, 2000; pp. 249-275.

38. Brenner, N.; Marcuse, P.; Mayer, M. Cities for people, not for profit: An introduction. In Cities for People, Not for Profit. Critical Urban Theory and the Right to the City; Routledge: New York, NY, USA, 2012; pp. 1-11.

39. Harvey, D. Globalization and the "spatial fix". Geog. Rev. 2001, 3, 23-30.

40. Mayer, M. The "right to the city" in the context of shifting mottos of urban social movements. City 2009, 13, 362-374. [CrossRef]

41. Kaika, M. “Don't call me resilient again!": The New urban agenda as immunology ... or ... what happens when communities refuse to be vaccinated with "smart cities" and indicators. Environ. Urban 2017, 29, 89-102. [CrossRef]

42. Hohmann, B. Strategies for a sustainable energy transition: The case of the housing sector in Graz, Austria. IOP Conf. Ser. Earth Environ. Sci. 2019, 323, 012180. [CrossRef]

43. Hoffer, K.U. Live Graz Team. I LIVE GRAZ: Smart People Create Their Smart City; Klima und Energiefonds: Vienna, Austria, 2013. 
44. Stadt Graz. Kontrollbericht 2/20 zum Thema Steuerung des öffentlichen Personennahverkehrs in Graz (StRH-51748/2019). 2020. Available online: https://docplayer.org/178716247-Kontrollbericht-2-2020-zum-thema-steuerung-des-oeffentlichenpersonennahverkehrs-in-graz-wirtschaftlichkeitskontrollen.html (accessed on 12 July 2021).

45. Stadt Graz. Leitlinien für BürgerInnenbeteiligung. 2020. Available online: https://www.graz.at/cms/beitrag/10244969/7755171 /Leitlinien_fuer_BuergerInnenbeteiligung.html (accessed on 12 July 2021).

46. Holding Graz. Unternehmensberichte. 2020. Available online: https://www.holding-graz.at/integrierterbericht.html (accessed on 12 July 2021).

47. Servus Abfall Dienstleistungs GmbH. Zukunftsfähige Lösungen für Unsere Kunden und eine Lebenswerte Region. 2021. Available online: https:/ / www.servus.st/wp-content/uploads/Servus-Leitbild.pdf (accessed on 30 March 2021).

48. EU-Recycling + Umwelttechnik. Intelligente Abfallwirtschaft 4.0: Wie Branchenunternehmen die Möglichkeiten der Digitalisierung Nutzen. 2020. Available online: https:/ / eu-recycling.com/Archive/26438 (accessed on 12 July 2021).

49. Land Steiermark, Amt der Steiermärkischen Landesregierung Abteilung 13. UVP-Genehmigungsbescheid für die Errichtung und Betrieb der Unterführung Josef-Huber-Gasse (ABT13-11.10-418/2016-279). 2020. Available online: https:/ /www.umwelt. steiermark.at/cms/dokumente/12627170_6392227/057687bd/279\%20Bescheid\%20Josef\%20Huber\%20Gasse_SIG.pdf (accessed on 12 July 2021).

50. ÖKO-service. Re-Use im Städtischen Raum Raum: State of the Art; Klima-und Energiefonds: Vienna, Austria, 2018.

51. Austria Presse Agentur. Big Belly: High-Tech Abfall-Tonne (presst) mit Sonnenkraft. 2021. Available online: https://www. ots.at/presseaussendung/OTS_20091001_OTS0338/big-belly-high-tech-abfall-tonne-presst-mit-sonnenkraft-bild (accessed on 12 July 2021).

52. ORF Steiermark. Sprechende Mülltonne Gegen Plastik im Biomüll. 2020. Available online: https://steiermark.orf.at/stories/30 75856/ (accessed on 12 July 2021).

53. Smart Waste: Wenn Mülltonnen Mitdenken. 2019. Available online: https://oe3.orf.at/stories/2956739 (accessed on 14 August 2021).

54. Lamnek, S.; Krell, C. Qualitative Sozialforschung: Lehrbuch, 5th ed.; Beltz: Weinheim, Germany, 2016.

55. Thompson, J.B. Critical Hermeneutics: A study in the Thought of Paul Ricoeur and Jürgen Habermas; Cambridge University Press: Cambridge, UK, 1981.

56. Grossi, G.; Pianezzi, D. Smart cities: Utopia or neoliberal ideology? Cities 2017, 69, 79-85. [CrossRef]

57. Stadt Graz. Zahlen + Fakten: Bevölkerung, Bezirke, Wirtschaft, Geografie. 2020. Available online: https://www.graz.at/cms / beitrag/10034466/7772565/Zahlen_Fakten_Bevoelkerung_Bezirke_Wirtschaft.html (accessed on 12 July 2021).

58. Eurostat. Bevölkerung am 1. Januar Nach Breite Altersgruppe, Geschlecht und Metropolregionen. 2021. Available online: http:/ / appsso.eurostat.ec.europa.eu/nui/show.do?dataset=met_pjanaggr3\&lang=de (accessed on 12 July 2021).

59. Stadt Graz. Smart City Graz. 2021. Available online: https://www.graz.at/cms/beitrag/10195399/8119940/Smart_City_Graz. html (accessed on 12 July 2021).

60. Eigentümerboard Reininghaus. 2021. Available online: https:/ / reininghausgründe.at/ (accessed on 20 March 2021).

61. Kreuzer, B. Der Bau der Autobahnen und Schnellstraßen in Österreich. In Das Autobahnnetz in Österreich; Asfinag., A., Ed.; Autobahnen- und Schnellstraßen-Finanzierungs-Aktiengesellschaft: Vienna, Austria, 2012; pp. 11-120.

62. Brunner, F. Planungswerkstatt. Zeit für Graz. BürgerInnenbeteiligung im Rahmen der Werkstatt Graz. GeoGraz 2008, 42, 16-19.

63. Rogers, H. Garbage capitalism's green commerce. In Socialist Register 2007. Coming to Terms with Nature; Panitch, L., Leys, C., Eds.; The Merlin Press: London, UK, 2006; pp. 231-253.

64. Winiwarter, V. History of waste. In Waste in Ecological Economics; Bisson, K., Proops, J., Eds.; Edward Elgar Publishing: Cheltenham, UK, 2002; pp. 38-54.

65. Gregson, N.; Crang, M. Materiality and waste: Inorganic vitality in a networked world. Environ. Plan A Econ. Space 2010, 42, 1026-1032. [CrossRef]

66. Blanding, M. Bigbelly's Big Bet on the Digital Trash Can. 2016. Available online: https://hbswk.hbs.edu/item/bigbelly-thetrash-can-and-business-model-of-the-future (accessed on 30 March 2021).

67. Servus Abfall Dienstleisungs GmbH. E-Müllauto im Testbetrieb in Graz. 2020. Available online: https://www.servus.st/zeroemission-e-muellauto-im-testbetrieb-in-graz/ (accessed on 12 July 2021).

68. Strüver, A. (Department of Geography and Regional Science, University of Graz, Austria); Ursula Hauszer (Friedensbüro Graz, Graz, Austria). Personal communication, 2020.

69. Saubermacher. Guter Nachbar Sein: Saubermacher Errichtet Lärmschutzwand Samt Neuem Lebensraum in Graz. 2021. Available online: https:/ / saubermacher.at/presse/saubermacher-errichtet-laermschutzwand-am-standort-puchstrasse-in-graz/ (accessed on 14 August 2021).

70. Hellwig, C.; Häggblom-Kronlöf, G.; Bolton, K.; Rousta, K. Household waste sorting and engagement in every-day life occupations after migration-A scoping review. Sustainability 2019, 11, 4701. [CrossRef]

71. Lepawsky, J. Reassembling Rubbish. Worlding Electronic Waste; MIT Press: Cambridge, MA, USA, 2018.

72. Liboiron, M. The What and the Why of Discard Studies. 2018. Available online: https://discardstudies.com/2018/09/01/thewhat-and-the-why-of-discard-studies / (accessed on 12 July 2021).

73. Stadt Graz. 2021. Available online: http:/ / www.smartcitygraz.at/ (accessed on 20 March 2021). 
74. Scheiner, J. Housing mobility and travel behaviour: A process-oriented approach to spatial mobility: Evidence from a new research field in Germany. J. Transp. Geogr. 2006, 14, 287-298. [CrossRef]

75. Caritas. 2021. Available online: https://www.caritas-steiermark.at/hilfe-angebote/menschen-in-not/arbeit-beschaeftigung (accessed on 14 August 2021).

76. Blühdorn, I.; Deflorian, M. The collaborative management of sustained unsustainability: On the performance of participatory forms of environmental governance. Sustainability 2019, 11, 1189. [CrossRef]

77. Foth, M.; Schroeter, R. Enhancing the experience of public transport users with urban screens and mobile applications. In Proceedings of the 14th International Academic MindTrek Conference: Envisioning Future Media Environments, Tampere, Finland, 6-8 October 2010.

78. RATP. Multimodal, Multimedia Information in Real-Time. 2018. Available online: https://www.ratp.fr/en/groupe-ratp/ passenger-information-operating-system/multimodal-multimedia-information-real-time (accessed on 14 August 2021).

79. Stadt Graz. Errichtung Straße u. Unterführung Josef Huber Gasse-Alte Poststraße. 2020. Available online: https://www.graz.at/ cms/beitrag/10298221/7769828?vid=413 (accessed on 20 March 2021).

80. Smigiel, C. Urban political strategies in times of crisis: A multiscalar perspective on smart cities in Italy. Eur. Urban Reg. Stud. 2018, 26, 336-348. [CrossRef]

81. Smigiel, C. Behind the smart city. Theoretical arguments and empirical findings of a multiscalar strategy in Austria. Geogr. Z. 2020, 108, 39-62. [CrossRef]

82. Harrison, K. Who is the assumed user in the smart city? In Designing, Developing, and Facilitating Smart Cities; Angelakis, V., Tragos, E., Pöhls, H.C., Kapovits, A., Bassi, A., Eds.; Springer: Cham, Switzerland, 2017; pp. 17-32.

83. Zandbergen, D.; Uitermark, J. In search of the smart citizen: Republican and cybernetic citizenship in the smart city. Urban Stud. 2019, 57, 1733-1748. [CrossRef]

84. Zuboff, S. The Age of Surveillance Capitalism: The Fight for a Human Future at the Frontier of Power; Publication Affairs: New York, NY, USA, 2019.

85. Cinnamon, J. Social injustice in surveillance capitalism. Surveill. Soc. 2017, 15, 609-625. [CrossRef]

86. Kwan, M.P. Algorithmic geographies: Big data, algorithmic uncertainty, and the production of geographic knowledge. Ann. Am. Assoc. Geogr. Mobil. 2016, 106, 274-282.

87. Kitchin, R. Thinking critically about and researching algorithms. Inf. Commun. Soc. Soc. Power Algorithms 2017, 20, 14-29. [CrossRef]

88. Safransky, S. Geographies of algorithmic violence: Redlining the smart city. Int. J. Urban Reg. Res. 2019, 44, 200-218. [CrossRef]

89. Robinson, C.; Franklin, R.S. The sensor desert quandary: What does it mean (not) to count in the smart city? Trans. Inst. Br. Geogr. 2021, 46, 238-254. [CrossRef]

90. Arora, P. Unsurping public leisure space for protest: Social activism in the digital and material commons. Space Cult. 2015, 18, 55-68. [CrossRef]

91. Levenda, A.M.; Keough, N.; Rock, M.; Miller, B. Rethinking public participation in the smart city. Can. Geogr. 2020, 64, 344-358. [CrossRef]

92. Johnson, P.A.; Acedo, A.; Robinson, P.J. Canadian smart cities: Are we wiring new citizen-local government interactions? Can. Geogr. 2020, 64, 402-415. [CrossRef]

93. Thompson, M. What's so new about new municipalism? Prog. Hum. Geogr. 2020, 45, 317-342. [CrossRef]

94. Arugi, A.; Obendaal, N. From "smart in the box" to "smart in the city": Rethinking the socially sustainable smart city in context. J. Urban Technol. 2021, 28, 55-77. [CrossRef] 